\title{
En oppdagelsesreisende
}

\author{
Som fersk assistentlege snublet Arne Røseth over en markør for aktiv betennelse \\ hos pasienter med inflammatorisk tarmsykdom. Siden den gang har han gått på ski \\ over Grønland og oppdaget at det koster å utfordre gamle sannheter.
}

I 1987 var Arne Røseth 31 år og nyutdannet lege og klamret seg til det han betegner som et «grått vikariat» ved Aker sykehus ved å vise seg faglig engasjert og nysgjerrig. Spesielt fanget bruken av kliniske indekser for vurdering av inflammatorisk tarmsykdom hans interesse. Var det virkelig slik at man kunne vurdere hvor aktiv pasientens sykdom var bare ved å undersøke vedkommende på utsiden?

- Jeg gikk sammen med professoren på visitt, og ble først imponert over at han kunne identifisere så mange kliniske tegn som betydde at pasienten hadde residiv. Da jeg etter en stund spurte hvordan han visste dette, svarte han bare at man hadde kliniske indekser for ditt og datt. Han ble vel litt lei av masingen min, for en fredag sa han: «Arne, mandag og tirsdag tilbringer du på biblioteket. Der skal du undersøke validering av kliniske indekser, så kan du legge det frem på avdelingsmøtet på fredag.» Den gang var det ikke noe Medline eller Internett, så dette tok tid. Men vi hadde faks og fikk masse artikler fakset inn fra utlandet, forteller han.

\section{Tungrodd system}

Kanskje hadde professoren en idé om at dette prosjektet ville jekke den unge jyplingen litt ned? Slik skulle det visst ikke gå. I stedet skulle unge doktor Røseth komme til å holde et flammende innlegg der han sablet ned alle kliniske indekser når det kom til å vurdere aktivitet av inflammatorisk tarmsykdom. I Index Medicus fant han nemlig ingen holdepunkter for at den mye anvendte «Crohn's disease activity index» holdt mål.

- Konklusjonen var at det eksisterte svært lite forskning på validiteten av indeksene, og at dokumentasjonen av det som var publisert, var mangelfull eller fraværende. Dette var i 1987, og fortsatt brukes denne indeksen!

Han rister oppgitt på hodet og strekker på seg i lenestolen. Han har geleidet meg til avdelingens mest komfortable stoler, som på dagtid er reservert for pasienter som får intravenøs behandling.
- Når du sammenlikner resultater ved bruk av denne kliniske indeksen med histologiske og endoskopiske funn, er det ingen korrelasjon. Det sier vel litt om hvor sidrumpet og tungrodd systemet er? Saken er den at det ikke er noen som ønsker å legge hodet på hoggestabben og si at det er på tide å slutte å bruke indeksen. Vi godtar veldig mange «vedtatte sannheter» i medisinen. Jeg blir skikkelig stresset av den typen likegyldighet, sier Røseth og velter koppen med rykende varm kaffe. Fra egen presskanne selvfølgelig. Litt luksus må man kunne fremskaffe i en ellers knepen sykehustilværelse.

\section{På jakt etter markøren}

Men unge Røseths nysgjerrighet stoppet ikke der. Ikke jekket det han ned heller. Spiren var nemlig sådd, og nå mente den ferske assistentlegen at det vel måtte være mulig å finne en markør for aktiviteten av inflammatorisk tarmsykdom. Ikke nok med det - han mente at han kunne finne den selv! Han hadde nemlig kommet over en studie som virket lovende og som ifølge ham selv var en mulig «stang inn» for å finne markøren han lette etter. Professor Schjønsby ga ham to dager fri fra jobben for å sette opp en studie, sannsynligvis ikke med de aller største forhåpninger.

- Jeg mente at man kunne bruke alfa-1antitrypsinutskilling i feces som en markør på aktiv inflammasjon og tok kontakt med professor Magne Fagerhol, som jeg visste var «norgesmester» på alfa-1-antitrypsinutskilling i blod, for å få hjelp til det praktiske.

Det skulle vise seg å bli skjellsettende. Professor Fagerhol hadde nemlig et annet og bedre forslag til hva som kunne være en potensiell markør for aktiv tarminflammasjon. - «Det du er ute etter er vel egentlig granulocyttene? Jeg isolerte for noen år siden et protein fra granulocytter. Vi kan jo se om det er noe av det proteinet i disse ekstraktene dine,» sa han.

Asstentlege Røseth fant frem de 10-12 fecesprøvene sine og kjørte ELISA-test på dem. Da de satt igjen med et antall gule brønner tilhørende pasientene med inflammatorisk tarmsykdom og et antall blanke brønner fra tarmfriske, kunne ikke professoren annet enn hevde at dette var et historisk øyeblikk.

- I løpet av åtte timer hadde vi både bekreftet at vi kunne måle kalprotektin $i$ feces og at vi kunne plukke ut pasientene med inflammatorisk tarmsykdom. Jeg sov ikke så godt den natten, forteller Arne Røseth.

Med høy puls og hovne øyne troppet han opp på professorens kontor neste morgen. Følelsen av å ha snublet over noe banebrytende nytt hadde holdt hjernen i høygir natten over. Arne Røseth har selv Crohns sykdom og visste godt hvor plaget pasientene var. Kanskje kunne funnet brukes til å bedre situasjonen for noen, kanskje kunne dette være banebrytende nytt?

- Han ble først litt sur da jeg sa at jeg ikke hadde fått sjekket ut det med alfa-1antitrypsinutskilling, men han måtte etter hvert tenne pipen for å stagge sin iver over det vi hadde funnet, så engasjert ble han, forteller Røseth.

For den som måtte ha gått glipp av den relative nyvinningen fekaltest - kalprotektin er et kalsiumbindende protein som finnes i nøytrofile granulocytter. Ved skade på tarmslimhinnen på grunn av inflammasjon vil granulocyttene vandre ut i tarmlumen og forhøyede verdier av kalprotektin kan måles i avføringen. Dette fra en oversiktsartikkel i Tidsskriftet (1).

\section{Nysgjerrig}

Med «PreMed» fra San Diego, California, gikk Arne Røseth en unorsk skole hva jantelov angår. I USA ble medisinstudentene opplært til å tro på seg selv og fikk fordype seg på de fagfeltene som engasjerte dem. Det pirret nysgjerrigheten.

- Jeg fikk blant annet studere embryologi og molekylærbiologi i halvannet år samt økologi i to hele år før jeg tok resten av legeutdanningen i Oslo. Jeg må si jeg har hatt en ålreit doktorskole sånn sett. Kanskje har det bidratt til at jeg tør stille kritiske spørsmål. Siden er jeg bare blitt mer kritisk til de gamle dogmene og mener vi bør bli mer som ingeniørene, som bruker målebånd 

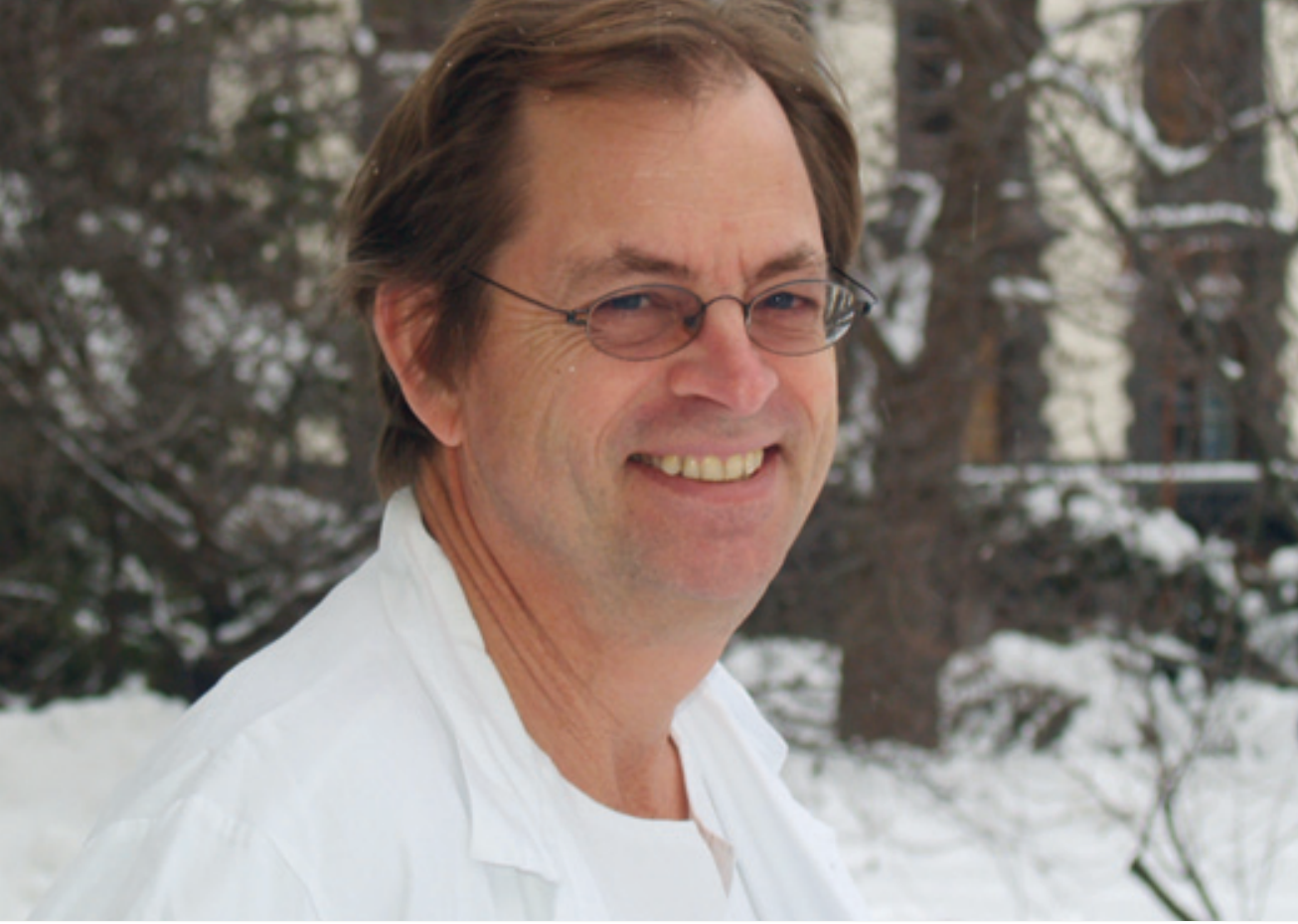

\section{Arne Gustav Røseth}

Født 3. oktober 1955

- PreMed San Diego State University, CA, 1980

- Cand.med. Universitetet i Oslo 1984

- Spesialist i indremedisin 1999 og i gastroenterologi 2001

- Ph.d. Universitetet i Oslo 1999

- Halv stilling som overlege i gastromedisin ved Lovisenberg Diakonale Sykehus

- Grunnlegger av firmaene Calpro AS og Lab-Tech A

Foto Anne Kathrine Sebjørnsen og vekt på alt de gjør og dermed kan kvalitetssikre sine data. Vi doktorer er jo ganske suverene - og dermed går vi også i vannet iblant.

- Hvordan ble din oppdagelse av fekalt kalprotektin mottatt?

- Jeg fikk i begynnelsen god kjennskap til janteloven. I Norge skal du jo helst stå med luen $\mathrm{i}$ hånden. Alle trodde $\mathrm{jeg}$ tjente masse penger på dette, hvilket ikke er tilfellet. Jeg har jo ikke holdt på med bæsj i 20 år for å bli rik. Det er ikke profitt, men interesse for faget som er min «driving force». Dessverre ble det etter hvert så plundrete for meg her at jeg trakk meg ut av miljøet en periode. Da jeg første gang presenterte funnet av fekalt kalprotektin på gastromedisinsk vintermøte, var det en deltaker som reiste seg opp og sa at dette var det største sludder han hadde hørt. Det var jo bare å ta en pasient med inflammatorisk tarmsykdom i hånden, så visste man hvor aktiv sykdommen var! Sånne kommentarer er ikke akkurat oppmuntrende.

Den manglende imøtekommenheten han opplevde i Norge, førte ham ut av landet. Han innledet etter hvert forskningssamarbeid med grupper ved både King's College i London, barneavdelingen i Aberdeen og Herlev sykehus i København. I 2004 ble kalprotektin FDA-godkjent, og etter hvert er det publisert et tilstrekkelig antall artikler om markøren til at Røseth ikke lenger blir beskyldt for å fare med sludder. Han er selv den første til å påpeke at markøren har sine klare begrensninger.

- Det er en god markør på granulocyttomsetningen i tarmen, men det kan nok mangle noe på spesifisiteten i enkelte sammenhenger, understreker han.

\section{Eventyreren}

Arne Røseths nysgjerrighet har ført ham langt, både faglig og geografisk. Nå har han over hundre reisedøgn $i$ året for å markedsføre fekaltesten, ellers er han å finne i halv overlegestilling ved gastromedisinsk avdeling ved Lovisenberg Sykehus. Når anledningen byr seg, legger han gjerne inn en liten ekspedisjon til mer eller mindre tilgjengelige reisemål. Og kona er en trofast følgesvenn - enten det er for å padle to tusen kilometer i den kanadiske villmarken eller legge ut på seiltur i iskaldt hav på Grønland eller Svalbard. Apropos Grønland - man må jo gå på ski over Grønland! Det var også konklusjonen til Arne Røseth og to av hans kolleger ved Aker universitetssykehus da de i 1996 tok skiene fatt og la ut på den strabasiøse turen.

- Det var i grunnen ganske morsomt både å planlegge og å gjennomføre ekspedisjonen. Vi tenkte at vi måtte gjøre noe vitenskapelig ut av det, og bestemte oss for å se på forholdet mellom fett og muskelmasse før og etter turen. Vi hadde gjort målinger av muskelmassen før vi la i vei med pulker på 80 kilo etter oss på isen. Vi mente jo at vi som doktorer hadde de beste forutsetninger for å ha et godt kosthold, og det skulle faktisk vise seg å stemme. For da vi etter tre uker ble hentet av en lokal innbygger, tvilte han litt på at vi virkelig hadde krysset innlandsisen. Han hadde nemlig aldri før hentet en så blid og velfødd gjeng, humrer Røseth.

Ny måling av muskelmassen viste at den faktisk hadde økt! Dette vakte oppsikt i NATO, som den gang vurderte den frysetørkede maten ekspedisjonsmedlemmene brukte som fremtidig stridsrasjon for soldatene sine.

- Det endte med at jeg ble invitert til å holde foredrag om kosthold under strabasiøse forhold i arktiske strøk på NATOtoppmøtet kort tid etter! Det er mye rart doktorer kan brukes til, ler han.

- Av kjente blir du karakterisert som en som fikser og ordner ting, og de mener at du liker en utfordring. Er du en eventyrer?

- Det er jo blitt en del turer etter hvert, i både kalde og varme strøk. Jeg må nok innrømme at det som gir meg mest glede, er å planlegge turen og gjøre de riktige forberedelsene, for så å se at man er i stand til å håndtere vanskelighetene når de dukker opp underveis. Det fine med problemer er jo at man kan løse dem. Jeg er nok en oppfinnertype som liker å være kreativ og utforske verden, så det er kanskje riktigere å si at jeg er problemløser heller enn eventyrer?

- Du har patentrettigheter i flere land til kommersiell bruk av kalprotektin i feces. Hvordan er det å være både gründer, næringsdrivende, forsker og sykehusansatt overlege?

- Jeg liker ikke å se på meg selv som kommersiell, og er veldig stringent overfor meg selv så jeg ikke skal havne i interessekonflikter. Jeg opplever ofte at jeg blir invitert med for å utforme nye forskningsprosjekter, men at jeg ikke får være med videre i prosjektet fordi det ville være en sammenblanding av roller. Det får jeg vel bare finne meg i. Men jeg er nok i bunn og grunn en sirkushest, og de trives som kjent best i manesjen.

\section{Anne Kathrine Sebjørnsen \\ annekaths@hotmail.com}

BUP Nordstrand

\footnotetext{
Litteratur

1. Jahnsen J, Røseth AG, Aadland E. Måling av kalprotektin i feces. Tidsskr Nor Legeforen 2009; 129 $743-5$.
} 